\title{
Peripheral T-cell Lymphoma Prognostic Index Score
}

National Cancer Institute

\section{Source}

National Cancer Institute. Peripheral T-cell Lymphoma Prognostic Index Score. NCI

Thesaurus. Code C161790.

A list of four factors to assess how an individual with peripheral T-cell lymphoma might respond to treatment and predict the risk of disease recurrence. The factors are:

patient's age, LDH levels: serum levels often correlate with the amount of tumor in the body, performance status, and bone marrow involvement. 